\title{
Erkek infertilitesi ve erektil disfonksiyon tedavisinde tamamlayıcı tıp: Moleküler düzeyde etki mekanizmaları ve klinik sonuçlar
}

\author{
Complementary medicine in the treatment of male infertility and erectile \\ dysfunction: Molecular effect mechanisms and clinical outcomes
}

Osman Can®, Lütfi Canatఠ

\section{öz}

Erektil disfonksiyon ve infertilite erkek cinsel sağlığındaki en sık karşılaşılan problemlerdendir. Erkek faktörüne bağlı infertilitelerin yaklaşık yarısının etyolojisi hala tam olarak aydınlatılamamıștır. İdiyopatik infertilitenin tedavisinde modern tıbbın tedavilerine ek olarak tamamlayıcı tıp seçenekleri de artık günümüzde oldukça sık tercih edilmektedir. Erektil disfonksiyonun tedavisinde de eskilerden beri bitkisel kökenli geleneksel tedaviler kullanılmıştır. Tamamlayıcı tıbbın son zamanlarda modern tıp alanında kullanımının artmasıyla bitkisel kökenli bu ajanlar, hastalar tarafından da sıkça tercih edilmektedir. Tamamlayıcı tıp tedavilerinde gebelik ve canlı doğum oranlarıyla ilgili henüz yeterli kanıt olmamasına rağmen yardımcı üreme yöntemlerinin bir parçası olarak subfertil erkeklere etkinliği kanıtlanmış antioksidanlar ve fitoteröpatik ajanlar önerebilir. Erektil disfonksiyon tedavisinde kullanılan bitkisel ajanların etki mekanizmaları net olarak aydınlatılamamıș olsa da nitrik oksit sentaz aktivitesinde ve testosteron düzeyindeki artışı sağlayarak etkilerini gösterdikleri düşünülmektedir. Erektil disfonksiyon ve erkek infertiltesi tedavisinde tamamlayıcı tıp ajanlarının etkinliğinin güçlü olarak gösterilebilmesi için ileri düzey çalışmalara ihtiyaç vardır.

Anahtar Kelimeler: Tamamlayıcı tıp, erkek infertilitesi, erektil disfonksiyon

\section{Gíiș}

En az bir yıl boyunca korunmadan ve düzenli cinsel ilişkiye rağmen gebelik oluşmamasına infertilite denilmektedir. Dünyada çiftlerin \%15 kadarının infertiliteden etkilendiği tahmin edilmektedir. ${ }^{[1]}$ İnfertilite olgularının \%20-50 kadarından erkek faktörü sorumlu tutulmaktadır. Erkek

Sağlık Bilimleri Üniversitesi, Okmeydanı Eğitim ve Araştırma Hastanesi, Üroloji Kliniği, istanbul, Türkiye

\section{Yazışma Adresi/ Correspondence:}

Osman Can

Halide Edip Adıvar Mahallesi Halide Edip Adıvar Ceddesi Nur Apt. No 3 D: 10, Şişli

34077, Istanbul, Türkiye

Tel: $\quad$ +902123145555/5243

E-mail:dr.osmancan01@gmail.com

Geliş/ Received: $\quad 01.06 .2019$

Kabul/ Accepted: 09.08 .2019

\section{ABSTRACT}

Erectile dysfunction and infertility are the most common problems in male sexual health. The etiologies of approximately half of the male factorrelated infertility is still unclear. In addition to the modern medicine treatments, complementary medicine options are preferred frequently in the treatment of idiopathic infertility. Traditional treatments of herbal origin were used in the treatment of erectile dysfunction since ancient times. With the increasing use of complementary medicine in modern medicine, these herbal agents are frequently preferred by patients. The effect mechanism of herbal agents used in the treatment of erectile dysfunction is not clear exactly. However, it is considered that they show their effects by increasing nitric oxide synthase enzyme and testosterone levels. Anti-oxidant and phytotherapeutic agents can be recommended to subfertile men as a part of assisted reproductive methods although there is not enough evidence about live birth and pregnant rates. Further studies are needed to demonstrate the efficacy of complementary medicine agents in the treatment of erectile dysfunction and male infertility.

Keywords: Complementary medicine, male infertility, erectile dysfunction

faktörüne bağlı infertilitenin $\% 30-40{ }^{\prime}$ ının ise etiyolojisi net bilinmemektedir. ${ }^{[2]}$ İdiyopatik infertilitenin tedavisinde yaşam tarzı değişiklikleri, hormonal terapiler ve tamamlayıcı tıptan faydalanılmaktadır.

Tamamlayıcı tıp günümüz modern tıbbın etkisini azaltmadan hastanın durumuna ek fayda sağlayacak uygulamalardır. Amerikan Ulusal Tamamlayıcı/Alternatif Tip Merkezi (NCCAM) Tamamlayıcı Tibbı; klasik tıbbın tam olarak bir parçası olarak kabul edilmeyen, medikal ve sağlık bakım sistemleri, yöntemler ve ürünler gibi çeşitliliğe sahip bir grup uygulama olarak tanımlamaktadır. ${ }^{[3]}$ Erkek infertilitesinin tedavisinde kullanılan tamamlayıcı tedavi yöntemleri Tablo 1'de gösterilmiştir. ${ }^{[4]}$ Günümüzde tamamlayıcı tıp uygulamaları hastalar tarafından da sıkça tercih edilmektedir. Kanada'da infertilite merkezine başvuran 
Tablo 1. Erkek infertilitesinde kullanılan tamamlayıcı tedavi yöntemleri

\begin{tabular}{lll}
\hline - Vitaminler-mineraller-Aminoa- & - Fitoterapi \\
sitler & - Masaj \\
- L-karnitin & - Aromaterapi/Akupunk- \\
- Asetil karnitin & \\
- Vitamin E & \\
- Vitamin C & \\
- Folik asit & \\
- Selenyum & \\
- Çinko & \\
- Koenzim Q10 & \\
- Omega-3 yağ asidi & \\
\hline
\end{tabular}

hastalardan yapılan bir çalışmada 500 erkekten \%31'inin bir veya daha fazla tamamlayıcı tedavi aldığını, tamamlayıcı tedavi alanların ise \%63'ünün antioksidan vitamin ve mineral takviyeleri aldığı belirlenmiştir. ${ }^{[5]}$ Yine İngiltere'de yapılan bir araştırmaya göre infertilite sebebiyle sağlık kuruluşuna başvuran kadınların \%63'ünün, erkeklerin ise \%25'inin tamamlayıcı tıp uygulamalarını kullandıklarını belirtmiştir. ${ }^{[6]}$

Erektil disfonksiyon (ED), seksüel birliktelik amaciyla penis ereksiyonunun tam sağlanamaması ya da devam ettirilememesi olarak tanımlanmaktadır. ED oldukça yaygındır ve erkeklerin \%5-20'si orta ve şiddetli derecede ED'ye sahiptir. ${ }^{[7]}$ Türk Androloji Derneği'nin ülkemizde yapt1ğı prevelans çalışmasına göre, Türkiye'nin 40 yaş ütü erkeklerdeki ED prevalansı \%33 olarak bildirilmiştir. ${ }^{[8]} \mathrm{ED}$ gelişimindeki risk faktörleri; egzersiz kısıtlllığı, obezite, metabolik sendrom, sigara içimi ve hiperkolesterolemidir. $\mathrm{Bu}$ risk faktörlerinin etkisi ile değişen endotelyal hücre fonksiyonu ve erektil fonksiyondaki azalma; nitrik oksit sentaz (NOS) aktivitesindeki azalmaya endotel bağımlı düz kas aktivitesindeki bozulmaya, Nitrik oksit (NO) biyoyararlanımındaki azalmaya dayandırılmaktadır. Azalan NO biyoyararlanımı ise LDL kolesterolün oksidasyonunda azalmaya, endotelyal disfonksiyona neden olan reaktif oksijen türlerinin oluşumuna ve vazodilatasyonda azalmaya neden olmaktadır. ${ }^{[9]}$ ED'nin patofizyolojik mekanizmaları anlaşıldıkça tedavi modaliteleri de bu yönde geliştirilmiştir. Hastalığın tedavisinde düzeltilebilir risk faktörlerinin düzenlenmesi ve yaşam tarzı değişiklikleri, Fosfodiesteraz-5 inhibitörleri gibi medikal tedaviler, intrakavernozal enjeksiyon tedavileri ve penil protezler gibi invaziv işlemlere varan tedavi modaliteleri geliştirilmiştir.

ED tedavisinde eskilerden beri Uzakdoğu ve Asya ülkelerinde geleneksel bitkisel kökenli ilaçlar kullanılmaktadır. Tamamlayıcı tıbbın son zamanlarda modern tıp alanında kullanım eğiliminin artmasıyla fitoterapik ilaçların hastalar tarafından da çok tercih edildiği bilinmektedir.
$\mathrm{Bu}$ derlemenin amacı erkek infertilitesi ve erektil disfonksiyonunda tamamlayıcı tedavi yöntemlerinin, etki mekanizmalarının tanımlanması ve klinik çalışmaların sunulmasıdır.

\section{INFERTIL HASTALARDA TAMAMLAYICI TEDAVI YÖNTEMLERININ ETKI MEKANIZMALARI}

\section{Antioksidatif Mekanizma}

Serbest oksijen radikalleri dış yörüngesinde eşlenmemiş elektronlara sahip aşırı reaktif kimyasal türlerdir. Bu reaktif bileşikler kararlı hale gelebilmek adına dış yörüngesindeki elektronunu ortaklaması gerekmektedir. Bu yüzden diğer moleküllerle reaksiyona girebilecek aktif bir yapı gösterirler. Bu reaktif ürünler metabolizmada oksijenin kullanıldığı reaksiyonlar sonucunda oluşurlar. Serbest radikaller hücre hasarındaki ve mikroorganizmaların öldürülmesindeki rollerine ek olarak, düşük konsantrasyonlarda hücrelerdeki sayısız sinyalizasyon yolağında, dolayısıyla birçok fizyolojik reaksiyonda da rol oynar. ${ }^{[0]}$ Serbest oksijen radikalleri bu nedenle hücrede normal olarak üretilir, ancak sağlıklı hücrelerde hücre içi konsantrasyonları, zararlı etkilerinin görülmemesi için sıkı bir şekilde düzenlenir. Dolayısıyla fizyolojik şartlarda serbest oksijen radikallerinin üretimi ve antioksidan sistemlerle yıkımı denge halindedir. İlerleyen yaş, ultraviyole ışınları, ilaç kullanımı, immün sistem reaksiyonları, radyasyon maruziyeti, stres, sigara ve alkol kullanımı gibi iç ve dış faktörler bu dengeyi bozabilir. Oluşan serbest radikaller hücre içi bileşenler ile kolayca etkileşime girerek oksidatif strese neden olurlar. ${ }^{[11]}$

Semendeki serbest oksijen radikallerinin en önemli kaynakları immatür spermatozoalar ve ejakulatta biriken lökositlerdir. Serbest radikallere bağlı olarak; sperm DNA ve mitokondri hasarı oluşur. Bunun sonucunda da protein sentezi ve enerji üretiminde bozulmalar görülür; hücre zarında lipid peroksidasyonu oluşur. Sonuç olarak serbest radikallerin bu olumsuz etkileri ile normal sperm yapısı ve hareketliliği bozulmakta, hücre zarındaki lipidlerin peroksidasyonuyla ortaya çıkan membran akıskanlığındaki bozukluk ile akrozomal reaksiyon defektleri ve sperm-ovum füzyon kusurları oluşmakta, DNA hasarı yoluyla sperm disfonksiyonu gelişmekte, hücre zarı bütünlüğünün bozulmasıyla hücre zarı geçirgenliğinde artış olmakta ve hücre ölümü gerçekleşmektedir. ${ }^{[12]}$

Antioksidanlar başlıca; serbest radikalleri nötralize eden ve serbest radikal hasarını tamir etmeye yardımcı olan maddelerdir. Antioksidan savunma sistemi; enzimatik ve non-enzimatik yollarla serbest oksijen radikallerini kararlı formlar 
haline getirirler. Enzimatik yolla etkili olanların başlıcaları; süperoksit dismutaz, katalaz, glutatyon peroksidaz, glutatyon transferaz, mitokondriyal sitokrom oksidaz ve hidroperoksidaz iken non-enzimatik yolla etkili olanların başlıcaları; melatonin, seruloplazmin, transferrin, miyoglobin, hemoglobin, ferritin, bilirubin, glutatyon, sistein, metiyonin, ürat, laktoferrin, albümin, askorbat, flavonoidlerdir.

\section{Uzun Zincirli Yağ Asitlerinin Mitokondri icçine Transportu ve Beta Oksidasyon ile Enerji Sağla- nımı (L-Karnitin, Koenzim Q10)}

L-karnitin, serbest yağ asidi metabolizmasında ve glukoz oksidasyonunda rol alan doğal bir aminoasit olarak kabul edilmektedir. Esas olarak yağ asitlerinin enerjiye dönüştürülmesinde görev alan esansiyel bir elementtir. ${ }^{[13]}$ Uzun zincirli yağ asitlerinin mitokondri içindeki oksidasyonu ancak L-karnitin varlığında olmaktadır. Serbest yağ asitleri, yağ açil-KoA sentetaz tarafından katalizlenen bir reaksiyon ile aktiflenir; yağ açil-KoA oluşur. Karnitin, yağ açil-KoA ile reaksiyona girer ve yağ açil karnitin oluşur. Reaksiyonu, karnitin palmitoil transferaz I katalizler. Oluşan yağ açil karnitin, karnitin açil translokaz tarafından mitokondri matriksine alınır. Matrikste yağ açil karnitinden karnitinin serbestleşmesi ile açil-KoA oluşur. Açil-KoA’nın mitokondri matriksinde beta oksidasyonu ile enerji elde edilir.

Koenzim Q10, vücutta bütün hücre membranlarında ve sperm hücresinin iç mitokondri zarında yer alır. Koenzim Q10; mitokondri iç zarında ATP sentezini sağlayan elektron taşıma zincirinde kofaktör olarak rol oynar. Koenzim Q10 kompleks I ve II'deki elektronların kompleks III'e taşınması ve kompleks III stabilizasyonundan sorumludur. Koenzim Q10'un bu mekanizmalarla serbest radikal oluşumunu azaltarak antioksidan etki gösterdiği bazı çalışmalarda da gösterilmiştir. ${ }^{[14]}$

\section{Antiapoptotik Etki (L-Karnitin, Çinko)}

Apoptozun oluşmasında proteaz ailesi olarak bilinen Kaspaz'lar rol oynamaktadır. Hücreler iki yolak ile apoptoza gidebilmektedir. Birinci yolak, ekstrensek: ölüm reseptörü yolağı olarak da bilinir. İkinci yolak olan intrensek yolak ise ölüm reseptörü yolağından farklı olarak hem hücre dışı sinyallerle (büyüme faktörü veya hormon azlığı, ultraviyole sşını, çeşitli sitokinler) hem de DNA hasarına neden olan hücre içi sinyallerle indüklenebilir.

L-karnitin, Bcl-2 ekspresyonunu arttırarak anti-apoptotik etki de göstermektedir. Çinko ise vücutta birçok önemli mekanizmada katalitik ve regülatör özellik gösteren bir iyondur; Testiküler steroidogeneziste, testis gelişiminde, spermatozoanın oksijen kullanımında, nükleer kromatin kümelenmesinde, akrozom reaksiyonunda, akrosin aktivitesinde, sperm kromatin stabilizasyonunda, testosterondan dihidrotestosteron oluşumunda önemli rol oynar. L-karnitin ve çinko ayrıca apoptotik programı başlatan ve yürüten çeşitli kaspazları ve FAS ile indüklenen apoptotik sinyallerin iletimini inhibe ederek antiapoptotik etki gösterirler.

\section{Tek Karbon Siklusu Üzerinden Etki (Folik asit, Sistein, B12 vit)}

Tek karbon metabolik siklusu antioksidatif mekanizmada hücresel metilasyon için oldukça önemlidir. Folik asit, B2, B3, B6, B12 gibi vitaminler bu siklusta rol alan önemli koenzimlerdendir. Homosisteinin metiyonine dönüşümü sırasında bu moleküllerin ortama hazır metil donörü vermeleri ile hiperhomosisteineminin önüne geçilmekte ve DNA bütünlüğü korunmaktadır. ${ }^{[15]}$ Ayrıca homosistein üzerinden başlı başına güçlü bir antioksidan olan glutatyon sentezlenir. Sperm vücutta en fazla metilasyon reaksiyonunun gerçekleştiği hücrelerden biridir ve bu metilasyon DNA bütünlüğü için, uygun gen ekspresyonu için ve fertilizasyon sonrası embriyo gelişimi için mutlaka gereklidir. ${ }^{[16]}$ Siklusta yer alan bu önemli koenzimlerin dışarıdan ilavesi ile tamamlayıcı tedaviler antioksidatif bir etki oluşturmaktadır.

\section{TAMAMLAYICI TEDAVI YÖNTEMLERINDEN BAZILARI VE KLINIIK ÇALIȘMALAR}

\section{L-Karnitin}

L-karnitin enerji üretiminde önemli rol oynayan, metiyonin ve lizin aminoasitlerinden oluşan, suda çözünebilen polar yapıya sahip bir moleküldür. L-karnitin uzun zincirli yă̆ asitlerinin mitokondri içine transportunu ve beta oksidasyonu sağlayarak metabolizmaya enerji sağlanmasına yardımcı olur. Oksidatif stres sonucu oluşan hasarın tamirini sağlayarak antiapoptotoik etki gösterirler. Ayrıca araşidonik asitin membran fosfolipidleri ile etkileşimini inhibe etme gibi önemli fonksiyonları vardır. Erkek infertilitesindeki etkisini antioksidatif ve antiapoptotik özellikleri ile sağlamaktadır. L-karnitin'in vücutta en fazla bulunduğu yer epididimin kaput kısmıdır. Epididim lümeninde karnitin ile etkileşen spermatozoa olgunlaşarak ileri hareketlilik kapasitesi kazanır. Ayrıca sertoli hücrelerine glukoz alımını uyararak testiküler sperm maturasyonunda görev almaktadir.

İdyopatik oligoastenozospermik hastalar üzerinde yapılan bir çalışmada karnitin tedavisinden sonra Malondialdehid 
(MDA) düzeylerinin azaldığı, semen volümünün arttığı, sperm motilitesi ve morfolojide düzelmeler olduğu görülmüştür. ${ }^{[17]}$ Yine 7 adet randomize kontrollü çalışmanın verilerinden oluşan, idyopatik oligoastenozospermik 751 hastanın değerlendirildiği bir metaanalizde, L-karnitin tedavisi sonrası spontan gebelik oranlarında anlamlı artışların olduğu görülmüştür. Ayrıca total sperm motilitesinde anlamlı artışların ve anormal morfolojili sperm yüzdesinde anlamlı azalmaların olduğu gösterilmiştir. ${ }^{[18]}$

\section{Koenzim Q10 (Ubikinon)}

Koenzim Q10, ubikinon ailesine ait, vücudun tüm hücre memranlarında ve sperm hücresi mitokondri iç zarında bulunan bir moleküldür. Mitokondri iç zarındaki ATP sentezini sağlayan elektron taşıma zincirinde kofaktör olarak görev alır. Ayrıca sperm membranında lipid peroksidasyonunu inhibe ederek ve superoksit anyon oluşumunu azaltarak antioksidan etki gösterir. ${ }^{[14]}$

Randomize plasebo-kontrollü bir çalışmada 60 idyopatik oligoastenoteratozospermik hastanın Koenzim Q10 tedavisi alan kolunda semendeki süperoksit dismutaz ve katalaz düzeylerinin Koenzim Q10 ile pozitif korele şekilde arttığı görülmüştür. Aynı zamanda Koenzim Q10 konsantrasyonu ile normal sperm morfolojisi ve sperm motilite oranlarında da anlamlı korelasyonlar tespit edilmiştir. ${ }^{[19]}$ Koenzim Q10 tedavisinin değerlendirildiği 3 plasebo-kontrollü çalışmadan derlenen bir metaanalize göre, tedavinin sperm motilitesi ve semen konsantrasyonlarında anlamlı artışa neden olduğu ancak canlı doğum ve gebelik gelişimine bir etkisinin olmadığı belirlenmiştir. ${ }^{[20]}$

\section{Selenyum}

Selenyum, hücre zarını oksidatif hasardan koruyan ametal bir elementtir. Toprakta saf ya da inorganik bileşikler halinde bulunur. Selenyum hücre zarlarını oksidatif hasarlardan koruyan glutatyon peroksidaz gibi önemli enzimlerin katalitik merkezinin aktif bölgelerinde selenosistein formunda yer almaktadır. ${ }^{[21]}$ Selenyum normal testiküler gelişim, spermatogenezis ve sperm kapasitasyon sürecinde gerekli olan bir elementtir. ${ }^{[22]}$

Selenyum eksikliğinin değerlendirildiği yakın zamandaki bir derlemede, semen kalitesinde ve sperm motilitesindeki bozulmaya neden olarak erkek infertilitesiyle ilişkili olabileceği belirtilmiştir. ${ }^{[23]}$ İnfertil 468 hasta üzerinde antioksidan ajan olarak selenyumun kullanıldığı bir çalışmada, selenyum tedavisinin hem sperm konsantrasyonu hem de motilite ve morfolojide anlamlı iyileşmeler sağladığı belirtilmiştir. $^{[24]}$

\section{Vitamini}

C vitamini (askorbik asit) esansiyel suda çözünebilen, güçlü bir antioksidandır. İnterselüler matriksin komponentlerinden birisidir ve kollajen ile proteoglikan sentezinde görev alır.

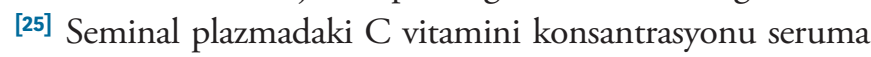
kıyasla yaklaşık 10 kat daha fazladır. Ayrıca seminal plazmadaki antioksidan kapasitenin \%65'ine yakınını oluşturur. ${ }^{[26]}$

Seminal vitamin C düzeyinin semen parametreleri üzerine etkisinin araştırıldığı hem fertil hem de infertil hasta gruplarının dahil edildiği bir çalışmada, seminal vitamin C düzeylerinin infertil hastalarda anlamlı oranda düşük olduğu saptanmış; sperm morfolojisi ile seminal C vitamini düzeyi arasında da anlamlı korelasyon olduğu belirtilmiştir. ${ }^{[27]}$ Seminal C vitamini düzeyi ile sperm DNA fragmantasyon indeksi skoru ilişkisinin araştırıldığı bir çalışmada seminal C vitamini düzeyi düşük hastalarda DNA fragmantasyon indeksi skoru yüksek saptanmıştır. ${ }^{[28]}$ Güncel randomize, plasebo kontrollü bir çalışmada klinik varikoseli olan 115 infertil hastaya varikoselektomi yapıldıktan sonra 3 ay boyunca bir gruba vitamin $\mathrm{C}$, diğer gruba plasebo verilerek semen analizleri karşılaştırılmıştır. Vitamin $\mathrm{C}$ alan grupta motilite ve morfolojide anlamlı düzelme izlenirken sperm konsantrasyonları her iki grupta benzer bulunmuştur. ${ }^{[20]}$

\section{E Vitamini}

E vitamini, serbest radikallerin lipid peroksidasyonuyla yol açtığı hücre membran hasarını önlemede ve diğer antioksidanların aktivitesini düzenlemede önemli rol oynar. ${ }^{[30]}$ Ayrıca $\mathrm{E}$ vitamininin tek başına ya da $\mathrm{C}$ vitamini kombinasyonuyla DNA fragmantasyonunu düzelttiği ve spermatozoanın zona pellicuda’ya bağlanmasını kolaylaştırdığı gösterilmiştir. ${ }^{[31]}$

Randomize plasebo kontrollü bir çalışmada normal kadın faktörlü 30 infertil erkek hastanın semenlerinde yüksek ROS görülmüştür. İki gruba ayrılan hastalara 3 ay boyunca E vitamini (600 mg/gün) ve plasebo tedavi verilmiştir. IVF yapilan hastalarda $\mathrm{E}$ vitamini verilenlerde spermin zona pellucida’ya bağlanma kapasitesinde anlamlı artış görülmüştür. [32] Diğer bir çalışmada ise önceki IVF sikluslarında düşük fertilizasyon oranı ve yüksek malondialdehit düzeyi olan normospermik 15 erkeğe 3 ay süreyle E vitamini (200 mg/ gün) tedavisi verilmiştir. Hastaların sperm morfolojisinde herhangi bir iyileşme görülmemesine rağmen siklus başına düşen fertilizasyon oranının \%19,3'den \%29,1'e yükseldiği, malondialdehit düzeylerinde ise anlamlı azalmalar olduğu görülmüştür. Düşük fertilizasyon başarısı olan normospermik erkeklerde E vitamininin lipid peroksidasyonunu azaltarak fayda sağladığı belirtilmiştir. ${ }^{[33]}$ 


\section{Çinko}

Metabolizmada çok sayıda önemli mekanizmalarda katalitik ve regülatör özellikler gösteren güçlü bir antioksidan iyondur. Çok sayıda makromolekülün fonksiyonunda görev alır ve 3000'in üzerinde proteinin yapısında rol oynamaktadır. Ayrıca DNA yapımı ve protein sentezinde rol alan çok sayıda enzimin esansiyel kofaktörüdür. ${ }^{[34]}$ Özellikle testiküler steroidogeneziste, testislerin gelişiminde, spermatozoanın oksijen kullanımı sırasında, nükleer kromatin kümelenmesinde, akrozom reaksiyonunda, akrosin aktivitesinde, sperm kromatin stabilizasyonunda ve testosterondan dihidrotestosteron oluşumunda önemli görevleri vardır. ${ }^{[35]}$

Çinko eksikliği durumunda oligospermi, hipogonadizm ve immün sistem fonksiyonlarında bozulmalar olduğu bildirilmiştir. ${ }^{[36]}$ Literatürde, astenozoosermisi olan 100 hastanın değerlendirildiği plasebo kontrollü bir çalışmada, çinko tedavisi sonunda sperm sayısı ve hareketliliği ile fertilizasyon kapasitesinde kontrol grubuna göre anlamlı artış, antisperm antikor düzeylerinde ise anlamlı azalmanın olduğu bildirilmiştir. ${ }^{[3]]}$ Fertil ve infertil hastalardaki seminal plazma çinko düzeylerinin karşılaştırıldığı randomize çift-kör plasebo kontrollü bir çalışmada infertil hastalarda seminal plazma çinko düzeylerinin daha düşük olduğu, seminal plazma çinko düzeyi ile sperm sayısı, motilitesi ve canlılığı arasında anlamlı pozitif korelasyon olduğu bildirilmiştir. ${ }^{[38]}$

\section{Folik Asit}

Folik asit, suda çözünen B grubu vitaminlerden birisi olup DNA sentezi, RNA transferi gibi görevlerinin yanında esansiyel aminoasitler için de oldukça önemlidir. En güçlü antioksidanlardan birisi olan glutatyon ve metiyonin oluşumunda diğer B vitaminleri ile etkileşime girerek önemli rol oynar. ${ }^{[39]}$ Bunun yanında lipid peroksidasyonunu inhibe ederek DNA ve hücre membranını serbest radikallere karşı korur. ${ }^{[35]}$

Seminal plazmadaki folik asit konsantrasyonunun düşük seviyelerde olmasının sperm DNA hasarı ile korele olduğu, hasar arttıkça da sperm motilite ve morfolojide bozulmaların olduğu gösterilmiştir. Yine seminal folik asit düzeyi düşüklüğü ile düşük sperm konsantrasyonu arasında bir korelasyon olduğu gösterilmiştir. ${ }^{[40]}$ Subfertil hastalardaki etkinliğinin değerlendirildiği randomize plasebo kontrollü bir çalışmada sperm konsantrasyonlarında artış sağlandığı ancak motilite ve morfoloji parametrelerinde etkili olmadığ bildirilmiştir. ${ }^{[38]}$ Başka bir randomize plasebo kontrollü çalışmada ise çinko ve folik asit kombinasyonu ile oligoastenoteratozoospermik subfertil hastalarda sperm fonksiyonlarında anlamlı düzelme gösterilmiştir. ${ }^{[41]}$

\section{Omega 3 Yağ Asitleri}

Omega 3 yağ asitleri metabolizma için gerekli olan ama vücutta üretilmeyen yağ asitleridir. Bu yüzden besinlerle alınamadığı takdirde gıda takviyeleri ile karşılanması gerekmektedir. Temel Omega 3 yağ asitleri; Alfa-linolenik asit (ALA), Eikosapentaenoik asit (EPA), Dokosaheksaenoik asit (DHA)'dır. Lipid yapıdaki çift katlı hücre zarının akışkanlığını sağlar. Bu sayede spermatozoanın başarılı fertilizasyonunu ve sperm-oosit füzyonunu kolaylaştırır. Süperoksit üretimini azaltma, glutatyon peroksidazı arttırma ve sperm DNA hasarını azaltma gibi fonksiyonları ile antioksidan özellik gösterir.

Oligoastenoteratozoospermik infertil hastaların değerlendirildiği randomize plasebo kontrollü bir çalışmada omega 3 yağ asidi tedavisi verilen grupta sperm sayısı, motilite ve morfolojilerinde plaseboya göre anlamlı iyileşmeler gözlenmiştir. ${ }^{[42]}$ Yapılan bir vaka-kontrol çalışmasında varikoseli olan ya da olmayan infertil hastalar ile fertil erkeklerin spermatozoasındaki omega 3 konsantrasyonları karşılaştırılmıştır. Varikoselli infertil grupta omega 3 düzeylerinin daha düşük olduğu aynı zamanda bu düşüklüğün varikosel derecesi ve sperm DNA hasarı ile korele olduğu gösterilmiştir. ${ }^{[43]}$

\section{FITOTERAPIK AJANLAR}

Fitoterapi, hastalıklardan korunmak ve tedaviyi desteklemek amacı ile tıbbi etkisi bilimsel olarak kanıtlanmış bitkiler, onların etkin maddelerini taşıyan kısımları ve/ veya bir işlem yoluyla elde edilmiş doğal ürünleri ile bunlardan hareketle hazırlanarak standardize edilmiş farmasötik formları (tablet, kapsül, vs) kullanılarak yapılan uygulamalardır. WHO verilerine göre dünya nüfusunun \%70-80'inin, kendi geleneksel kültüründeki bitkisel ilaçları tercih ettiğini göstermiştir. Bitkisel ajanların erkek infertilitesindeki başarısının mekanizaması tam olarak aydınlatılamamıştır. Ancak çalışmalardan elde edilen verilere göre en muhtemel mekanizmalar antioksidatif, antiinflamatuar, antiödematöz ve hormonal etkilerdir. Erkek inferitilitesinde etkili olduğu gösterilen fitoterapötik ajanlardan bazı örnekler verilmiştir.

\section{Crocus Sativus (Safran)}

Iridaceae ailesinden olan safran, ülkemizin haricinde Hindistan, Yunanistan, İspanya, Fransa, İran, Çin ve Cezayir gibi ülkelerde de yetiştirilmektedir. Antispazmotik, analjezik ve ekspektoran etkileri mevcuttur. Aynı zamanda içerdikleri karotenoidler sayesinde antioksidan özellik gösterirler. İdiyopatik infertilitesi olan 52 erkek hastaya üç 
ay süresince haftada üç kez $50 \mathrm{mg}$ safran ekstresi tedavisi verilmiştir. Tedavi sonrasında sperm morfolojisinde ve motilitelerinde anlamlı düzelmeler izlenmiştir. ${ }^{[4]}$

\section{Cinnamomum Zaylanicum (Tarçın)}

Günlük hayatta sıkça kullandığımız tarçın, içerdiği sinnamaldehit sayesinde güçlü bir serbest radikal süpürücü özellik gösterir. Tarçın anti-inflamatuar, anti-viral, anti-bakteriyel, anti-neopalstik, anti-hiperlipidemik özellikler gösterir. Ülkemizde yapılan deneysel bir çalışmaya göre; 10 hafta boyunca günlük $100 \mathrm{mg} / \mathrm{kg}$ tarçın kabuğu yağı verilen ratlarda testiküler malondialdehid düzeyinin azaldığı, katalaz, glutatyon peroksidaz ve glutatyon düzeylerinin anlamlı şekilde arttığı bildirilmiştir. Ayrıca yine bu çalışmada sperm parametrelerinin kontrol grubuna göre anlamlı şekilde iyileştiği gösterilmiştir. ${ }^{[45]}$

\section{Cucurbita Pepo (Kabak Çekirdeği)}

Tamamlayıcı tıpta önemli bir yeri olan kabak çekirdeği, yağ asitleri, fitosteroller, proteinler, karotenoidler, E vitamini, çinko ve selenyum açısından oldukça zengindir. Sperm hareketi için gerekli önemli moleküllerin prekürsörü olan arjinin aminoasidini yüksek oranda ihtiva ettiğinden infertiliteye pozitif bir katkısının olduğu düşünülmektedir. Deneysel bir çalışmada kabak çekirdeği ekstresi verilen ratlarda antioksidatif etki ile siklofosfamidin reprodüktif sistem üzerindeki istenmeyen etkilerin antagonize edildiği ve sperm parametrelerinde iyileşme sağlandığı gösterilmiştir. ${ }^{[46]}$

\section{Nigella Sativa (Çörek Otu)}

Çörek otu geçmişten günümüze dek romatizmal ve respiratuar hastalıklar ile erkek seksüel disfonksiyonu tedavilerinde yaygın olarak kullanılmıştır. İçerdiği timokinon ve karvakrol molekülleri ile semendeki rekatif oksijen radikallerini nötralize eder. İçerdiği zengin omega 3 yağ asidi sayesinde testosteron sentezindeki önemli enzimlerden birisi olan beta hidroksisteroid dehidrogenaz'n aktivitesini artırmaktadır. Oligoastenoteratozoospermik hastaların değerlendirildiği randomize çift-kör plasebo-kontrollü bir çalışmada 2 ay boyunca çörek otu tohumu yağı verilen grubun sperm parametrelerinde kontrol grubuna göre anlamlı şekilde düzelmeler gösterilmiştir. ${ }^{[47]}$

\section{Sesamum Indicum (Susam)}

Pedeliaceae ailesine ait, anavatanı Afrika olan bir bitki türüdür. Günümüzde Asya, Avrupa ve Türkiye'nin sıcak bölgelerinde de yetiştirilmektedir. İçerdiği zengin doymamış yağ asidi ve tokoferoller sayesinde antitümörojenik, antiöstrojenik ve antioksidan özellik gösterirler. İnfertil 25 hastanın değerlendirildiği klinik bir çalışmada, 3 ay susam tedavisi sonrasında hastaların sperm sayısı ve motilitesinde anlamlı düzelmelerin görüldüğü bildirilmiştir. ${ }^{[48]}$

\section{Punica Granatum (Nar)}

İçerdiği tanin, fenol ve flavonoidler sayesinde oksidatif stresi nötralize edici etkileri vardır. Ayrıca vücutta askorbik asit ve elajik asit düzeylerini arttırarak oksidatif DNA hasarını engeller ve böylece semen parametrelerini düzelttiği düşünülmektedir. Deneyesel bir çalışmada nar ekstresi verilen gruptaki ratlarda antioksidatif enzimlerin arttığ ve semen parametrelerinin iyileştiği gösterilmiştir. ${ }^{[49]}$

\section{Tribulus Terrestris (Demir Dikeni)}

Eski tarihlerden bu yana geleneksel tıpta yaygın olarak kullanilan demir dikeni, diüretik, afrodizyak, antidiabetik, antienflamatuar, analjezik ve antibakteriyel özeliklere sahiptir. İçerdiği protodiosin molekülü sayesinde testosteron düzeyini arttırarak libido ve seksüel aktivite üzerine olumlu etkileri de mevcuttur. Güncel bir çalışmada semen parametreleri bozuk 65 infertil erkeğe 12 hafta boyunca demir dikeni ekstresi verilmiştir. Tedavi sonrasında sperm sayı ve hareketinde anlamlı artış bildirilmiştir. ${ }^{[50]}$

\section{Zingiber Officiale (Zencefil)}

Dünyada yaygın olarak kullanılan antioksidan ve antienflamatuar özellikleri olan bir fitoterapi ajanıdır. İnfertil 100 erkeğin değerlendirildiği randomize kontrollü çift-kör bir çalışmada zencefil tedavisi alan grupta sperm DNA fragmantasyonunun anlamlı şekilde azaldığı ancak semen parametrelerinde önemli bir değişiklik olmadığı bildirilmiştir. ${ }^{\left[{ }^{[1]}\right.}$ Bir çok deneysel çalışmada zencefilin semen parametrelerini iyileştirdiği gösterilmiştir. ${ }^{[52]}$

\section{Panax Ginseng (Kore Ginsengi)}

Uzak doğu'da yetiştirilen bir bitki türü olan Kore ginsenginin birçok kanser tedavisinde, diabetes mellitusta, hipertansiyonda, Alzheimer hastalığında ve cinsel fonksiyon bozukluklarında etkili olduğu düşünülmektedir. Bu etkilerini antioksidan özellikleri ile oluşturduğu sanılmaktadır. Varikosele sahip 80 infertil erkeğin değerlendirildiği randomize plasebo kontrollü bir çalışmada hastalar üç ay boyunca Kore ginseng tedavisi verilmiştir. Varikoselektomi operasyonu sonrası Kore ginseng tedavisi alan hastalarda plasebo grubuna göre sperm sayı, hareket ve morfolojisinde anlamlı düzelmeler olduğu bildirilmiştir. Tedavi süresince olumsuz bir yan etki bildirilmemiştir. 


\section{ERKEK INFERTILITESINDE}

\section{VARIKOSELEKTOMI SONRASI TAMAMLAYICI TEDAVININ ETKINLIĞi}

Varikosel erkek infertilitesinin en sık nedenlerinden birisidir. Reaktif oksijen radiakallerinin hasarı, hormonal bozukluklar, artmış skrotal ısı, testiküler perfüzyon bozukluğu ve renal/adrenal venöz sisteminin reflüsü varikoselin muhtemel patofizyolojileri arasındadır. ${ }^{[53]}$ Varikosel tedavisinde cerrahi altın standart olmasına rağmen varikoseli olan her hastanın infertil olmadığı ve her varikoselektomi operasyonu olan hastanın da fertilite kazanamayabileceği bilinmektedir. ${ }^{[54]}$ $\mathrm{Bu}$ nedenle varikoselektomi operasyonuyla kombine olarak tamamlayıcı tedavilerin kullanımı semen parametreleri üzerinde iyileştirici etkileri olabileceği düşünülmüştür. Güncel bir randomize kontrollü çalışmada infertil hastalardan oluşan iki gruptan birisine yalnızca varikoselektomi operasyonu uygulanırken, diğer gruba operasyon sonrası 6 ay boyunca antioksidan ajan tedavisi uygulanmış. Kombine tedavi alan grupta klinik gebelik oranlarının daha yüksek olduğu bildirilmiştir. ${ }^{[55]}$ Randomize kontrollü çalışmalardan elde edilen bir metaanalize göre varikoselektomi sonrası adjuvan tamamlayıcı tedavi alan grupta klinik gebelik oranlarında anlamlı bir değişiklik görülmez iken antioksidanlar ile 3. ay sperm motilite ve sperm DNA bütünlüğünde anlamlı artı̧̧ olduğu bildirilmiştir. ${ }^{[56]}$

\section{EREKTIL DISFONKSIYONUN TEDAVISINDE KULLANILAN TAMAMLAYICI TEDAVi AJANLARI VE ETKI MEKANIZMALARI}

\section{Ginseng (Panax)}

Araliaceae ailesinin 11 türünden birisidir. Geleneksel tıpta Uzakdoğu ülkelerinde hipertansiyon, diyabet, kanser ve astım gibi hastalıkların tedavisinde yaygın olarak kullanılmıştır. Antienflamatuar, antioksidan ve antiapoptotik etki gösterirler. Aktif bileşenleri ginsenosides ve saponin glikozitleridir. ED tedavisindeki etkilerini cGMP üzerinden penil düz kas gevşemesi ve NO ekspresyonunda artış gösterirler. Randomize kontrollü çalışmalardan elde edilen bir metaanalize göre 8 hafta boyunca Ginseng tedavisinin ED tedavisinde plaseboya göre anlamlı olarak üstün olduğu gösterilmiştir. ${ }^{[57]}$

\section{Epimedium (Azgın Teke Otu)}

Berberidaceae ailesinin bir üyesi olan 60 türden ikisi olan E. grandifloeum ve E. sagittatum ED tedavisinde kullanılırlar. İçerdikleri major aktif bileşenler icariin ve epimidin A, B, C'dir. Icariin, epimediumun içinde en fazla bulunan ve ereksiyona en fazla katkı sağlayan flavonoiddir.
Anjiogenezi VEGF'den bağımsız olarak aktive eder. Tirozin kinaz aşırı ekspresyonunu sağlayarak anjiogenezi doza ba$\breve{g} ı m l ı$ indükler. PDE5 enzimini spesifik olarak inhibe eder. Icariinin yapısal modifikasyonu ile PDE5'inin etkisini artırdığı gösterilmiştir. ${ }^{[58]}$

\section{Ginkgo Biloba}

Dünya üzerindeki en eski bitkilerden olan Ginkgo biloba, yaşayan fosil türlerinin en iyi örneklerinden birisi olarak kabul edilir. ABD'de kognitif bozukluk tedavilerinde en fazla kullanılan tamamlayıcı tedavi ajanlarından biridir. Periferik damar hastalığı, Alzheimer, demans, kronik vasküler yetmezlikle ilişkili hastalıklarda sıklıkla tercih edilmektedir. ED'deki asıl etkilerini vasoprotektif ve nöroprotektif yollarla gösterirler. Ayrıca beyin ve genital bölgelerde kan akımı artı̧ı ve NO biyoyararlanımını arttırma gibi etkileri de mevcuttur. Deneysel bir çalışmada kavernozal sinir hasarı sonrası Gingko tedavisi ile nNOS (+) sinirlerin korunduğu gösterilmiştir. Yine de Ginkgo biloba ile ilgili yeterli klinik çalışma henüz bulunmamaktadır. ${ }^{[59]}$

\section{Tribulus Terrestris (Demir Dikeni)}

Afrodizyak etkisi nedeni ile geleneksel tıpta yaygın olarak kullanılan ve infertilite üzerine de olumlu etkilerinden bahsettiğimiz bu ajanın testosteron seviyesini arttırarak erektil kapasiteyi arttırdığı düşünülmektedir. Randomize, prospektif, çift-kör dizayn edilen 100 hastanın değerlendirildiği bir çalışmada Tribulus Terrestris'in erektil fonksiyonlar ve serum testosteron düzeyi üzerinde iyileştirici bir etkisi tespit edilememiştir. ${ }^{[60]}$ Diğer bir randomize, plasebo-kontrollü prospektif çalışmada, erektil fonksiyonlar üzerinde plasebo grubuna göre olumlu etkilerinin olduğu bildirilmiştir. ${ }^{[6]}$

\section{Lepidium Meyenii (Maca)}

Turpgiller ailesinden olan Maca, uzun yıllardır geleneksel tıpta erkek cinsel sağlığı ve infertilite için kullanılmış bitkisel bir ajandır. İçerdiği; fitostenol, polifenol, fitosterol, fitoöstrojen, yağ asidleri ile etkilerini gösterdikleri düşünülmektedir. ED tedavisindeki etki mekanizması net değildir. Maca ile ilgili bir sistematik derlemede, ED üzerine sınırlı bir pozitif katkısının olduğu ve daha geniş çalışmalara ihtiyaç olduğu bildirilmiştir. ${ }^{[62]}$

\section{SONUÇ}

İdiyopatik erkek infertilitesinin tedavisinde tamamlayıcı tıptan faydalanılabilir. Tamamlayıcı tıbbın erkek infertilitesindeki etki mekanizmaları; antioksidatif mekanizma, uzun zincirli yağ asitlerinin mitokondri içine transportu ile 
enerji sağlanımı, antiapoptotik etki ve tek karbon siklusu üzerinden etki olarak sıralanabilir. Yardımcı üreme yöntemlerinin bir parçası olarak subfertil erkeklere etkinliği kanıtlanmış antioksidanlar ve fitoteröpatik ajanlar önerebilir. Ancak çiftlere, bu tedavilerin gebelik ve canlı doğum oranlarını artırma konusundaki güncel kanıtların henüz yeterli olmadığı belirtilmelidir.

Erektil disfonksiyonun tedavisinde uzun yıllardan beri kullanılan geleneksel tedavi yöntemlerinin etki mekanizmaları tam olarak açıklanamamış olsa da, sıklıkla nitrik oksit sentaz aktivitesinde ve testosteron düzeyindeki artış yoluyla gerçekleştiği preklinik çalışmalarla gösterilmiştir. Ancak klinik çalışmalarda erektil disfonksiyon tedavisi üzerine sınırlı katkısının olduğu ve iyi dizayn edilmiş randomize prospektif çalışmalara ihtiyaç olduğu görülmektedir.

\section{Hakem Değerlendirmesi}

Dış bağımsız

Çıkar Çatışması

Yazarlar çıkar ilişkisi olmadığını beyan etmişlerdir.

Finansal Destek

Herhangi bir mali destek alınmamıştır.

\section{Peer-review}

Externally peer-reviewed.

Conflict of Interest

No conflict of interest was declared by the authors.

Financial Disclosure

No financial disclosure was received.

\section{KAYNAKLAR}

1. Agarwal A, Mulgund A, Hamada A, Chyatte MR. A unique view on male infertility around the globe. Reprod Biol Endocrinol 2015;13. [CrossRef]

2. Turek P. Male reproductive physiology. In: Wein A, Kavoussi LR, Campbell MF, editors. Campbell-Walsh Urology, 10th ed. Philadelphia, Pa.: Elsevier/Saunders; 2012. pp.591-615.

3. Millet JD. Progress in Complementary and Alternative Medicine Research. Yale J Biol Med 2010;83(3):127-9. https://www.ncbi. nlm.nih.gov/pmc/articles/PMC2946125/

4. Yao D, Mills J. Male infertility: lifestyle factors and holistic, complementary, and alternative therapies. Asian J Androl 2016;18:410. [CrossRef]

5. Zini A, Fischer MA, Nam RK, Jarvi K. Use of alternative and hormonal therapies in male infertility. Urology 2004;63:141-3. [CrossRef]

6. Boivin J, Bunting L, Collins JA, Nygren KG. International estimates of infertility prevalence and treatment-seeking: Potential need and demand for infertility medical care. Hum Reprod 2007;22:1506-12. [CrossRef]

7. Hatzimouratidis K, Amar E, Eardley I, Giuliano F, Hatzichristou D, Montorsi F, et al. Guidelines on Male Sexual Dysfunction: Erectile Dysfunction and Premature Ejaculation. Eur Urol 2010;57:804-14. [CrossRef]

8. Kendirci M, Asci R, Yaman Ö, , S Çayan, Orhan I, Usta MF, et al. Prevalence of male pelvic dysfunction: Results from the Turkish society of andrology male sexual health study group. Andrology 2014;2:219-24. [CrossRef]
9. Ferrini M, Magee TR, Vernet D, Rajfer J, González-Cadavid NF. Aging-Related Expression of Inducible Nitric Oxide Synthase and Markers of Tissue Damage in the Rat Penis. Biol Reprod 2001;64:974-82. [CrossRef]

10. Cabello-Verrugio C, Simon F, Trollet C, Santibañez JF. Oxidative Stress in Disease and Aging: Mechanisms and Therapies 2016. Oxid Med Cell Longev 2017;2017:4310469. [CrossRef]

11. Ratnam DV, Ankola DD, Bhardwaj V, Sahana DK, Kumar MNVR. Role of antioxidants in prophylaxis and therapy: A pharmaceutical perspective. J Control Release 2006;113:189-207. [CrossRef]

12. Ko EY, Sabanegh ES, Agarwal A. Male infertility testing: Reactive oxygen species and antioxidant capacity. Fertil Steril 2014;102:1518-27. [CrossRef]

13. Caraccio T, Mofenson H. Carnitine. J Toxicol Clin Toxicol 2003;41:897. [CrossRef]

14. Nohl H, Gille L, Staniek K. The biochemical, pathophysiological, and medical aspects of ubiquinone function. Ann NY Acad Sci 1998;854:394-409. [CrossRef]

15. Singh K, Jaiswal D. One-carbon metabolism, spermatogenesis, and male infertility. Reprod Sci 2013;20:622-30. [CrossRef]

16. Kumar M, Kumar K, Jain S, Hassan T, Dada R. Novel insights into the genetic and epigenetic paternal contribution to the human embryo. Clinics 2013;68(S1):5-14. [CrossRef]

17. Nada EA, El Taieb MA, Ibrahim HM, Al Saied AERA. Efficacy of tamoxifen and L-carnitine on sperm ultrastructure and seminal oxidative stress in patients with idiopathic oligoasthenoteratozoospermia. Andrologia 2015;47:801-10. [CrossRef]

18. Shang X, Wang L, Mo D, Cai H, Zheng D, Zhou Y. Effect and safety of L-carnitine in the treatment of idiopathic oligoasthenozoospermia: a systemic review. Zhong Hua Nan Ke Xue 2015;21:65-73.

19. Nadjarzadeh A, Shidfar F, Amirjannati N, Vafa M, Motevalian S, Gohari M, et al. Effect of Coenzyme Q10 supplementation on antioxidant enzymes activity and oxidative stress of seminal plasma: A double-blind randomised clinical trial. Andrologia 2014;46:177-83. [CrossRef]

20. Lafuente R, González-Comadrán M, Solà I, López G, Brassesco M, Carreras R, Checa MA. Coenzyme Q10 and male infertility: A meta-analysis. J Assist Reprod Genet 2013;30:1147-56. [CrossRef]

21. Maiorino FM, Brigelius-Flohé R, Aumann KD, Roveri A, Schomburg D, Flohe L. Diversity of glutathione peroxidases. Methods Enzymol 1995;252:38-53. [CrossRef]

22. Ursini F, Heim S, Kiess M, Maiorino M, Roveri A, Wissing J, Flohe L. Dual function of the selenoprotein PHGPx during sperm maturation. Science 1999;285:1393-6. [CrossRef]

23. Pieczyńska J, Grajeta H. The role of selenium in human conception and pregnancy. J Trace Elem Med Biol 2015;29:31-8. [CrossRef]

24. Safarinejad MR, Safarinejad S. Efficacy of Selenium and/or N-Acetyl-Cysteine for Improving Semen Parameters in Infertile Men: A Double-Blind, Placebo Controlled, Randomized Study. J Urol 2009;181:741-51. [CrossRef]

25. Linster CL, Van Schaftingen E. Vitamin C: Biosynthesis, recycling and degradation in mammals. FEBS J 2007;274:1-22. [CrossRef]

26. Lewis SEM, Sterling ESL, Young IS, Thompson W. Comparison of individual antioxidants of sperm and seminal plasma in fertile and infertile men. Fertil Steril 1997;67:142-7. [CrossRef]

27. Colagar AH, Marzony ET. Ascorbic Acid in Human Seminal Plasma: Determination and Its Relationship to Sperm Quality. J Clin Biochem Nutr 2009;45:144-9. [CrossRef]

28. Song GJ, Norkus EP, Lewis V. Relationship between seminal ascorbic acid and sperm DNA integrity in infertile men. Int J Androl 2006;29:569-75. [CrossRef] 
29. Cyrus A, Kabir A, Goodarzi D, Moghimi M. The effect of adjuvant vitamin $\mathrm{C}$ after varicocele surgery on sperm quality and quantity in infertile men: A double blind placebo controlled clinical trial. Int Braz J Urol 2015;41:230-8. [CrossRef]

30. Brigelius-Flohe R, Traber MG. Vitamin E: function and metabolism. FASEB J 1999;13:1145-55. [CrossRef]

31. Greco E, Iacobelli M, Rienzi L, Ubaldi F, Ferrero S, Tesarik J. Reduction of the incidence of sperm DNA fragmentation by oral antioxidant treatment. J Androl 2005;26:349-53. [CrossRef]

32. Kessopoulou E, Powers HJ, Sharma KK, Pearson M, Russell J, Cooke I, Barratt CLR. A double-blind randomized placebo cross-over controlled trial using the antioxidant vitamin $\mathrm{E}$ to treat reactive oxygen species associated male infertility. Fertil Steril 1995;64:825-31. [CrossRef]

33. Geva E, Bartoov B, Zabludovsky N, Lessing JB, Lerner-Geva L, Amit A. The effect of antioxidant treatment on human spermatozoa and fertilization rate in an in vitro fertilization program. Fertil Steril 1996;66:430-4. [CrossRef]

34. Maret W. Zinc and human disease. In: Sigel A, Sigel H, Sigel R, editors. Interrelations between Essential Metal Ions and Human Diseases. Metal Ions in Life Sciences, vol 13. Springer, Dordrecht; 2013. pp.389-414. [CrossRef]

35. Ebisch IMW, Thomas CMG, Peters WHM, Braat DDM, SteegersTheunissen RPM. The importance of folate, zinc and antioxidants in the pathogenesis and prevention of subfertility. Hum Reprod Update 2007;13:163-74. [CrossRef]

36. Prasad AS. Zinc in human health: effect of zinc on immune cells. Mol Med 2008;14:353-7. [CrossRef]

37. Omu AE, Dashti H, Al-Othman S. Treatment of asthenozoospermia with zinc sulphate: Andrological, immunological and obstetric outcome. Eur J Obstet Gynecol Reprod Biol 1998;79:179-84. [CrossRef]

38. Wong WY, Merkus HMWM, Thomas CMG, Menkveld R, Zielhuis GA, Steegers-Theunissen RPM. Effects of folic acid and zinc sulfate on male factor subfertility: A double-blind, randomized, placebocontrolled trial. Fertil Steril 2002;77:491-8. [CrossRef]

39. Goszcz K, Deakin SJ, Duthie GG, Stewart D, Leslie SJ, Megson IL. Antioxidants in Cardiovascular Therapy: Panacea or False Hope? Front Cardiovasc Med 2015;2:1-22. [CrossRef]

40. Boxmeer JC, Smit M, Utomo E, Romijn J, Eijkemans M, Lindemans $\mathrm{J}$, et al. Low folate in seminal plasma is associated with increased sperm DNA damage. Fertil Steril 2009;92:548-56. [CrossRef]

41. Raigani M, Yaghmaei B, Amirjannti N, Lakpour N, Akhondi M, Zeraati $\mathrm{H}$, et al. The micronutrient supplements, zinc sulphate and folic acid, did not ameliorate sperm functional parameters in oligoasthenoteratozoospermic men. Andrologia 2014;46:956-62. [CrossRef]

42. Safarinejad MR. Efficacy of Coenzyme Q10 on Semen Parameters, Sperm Function and Reproductive Hormones in Infertile Men. J Urol 2009;182:237-48. [CrossRef]

43. Tang LX, Yuan DJ, Wang QL, Jiang F, Guo J, Tang Y, et al. Association of decreased spermatozoa omega-3 fatty acid levels and increased oxidative DNA damage with varicocele in infertile men: A case control study. Reprod Fertil Dev 2016;28:648. [CrossRef]

44. Heidary M, Vahhabi S, Reza Nejadi J, Delfan B, Birjandi M, Kaviani H, Givrad S. Effect of saffron on semen parameters of infertile men. Urol J 2008;5:255-9. http://journals.sbmu.ac.ir/ urolj/index.php/uj/article/view/34/33

45. Yüce A, Türk G, Çeribaşi $S$, Sönmez $M$, Çiftçi $M$, Güvenç $M$. Effects of cinnamon (Cinnamomum zeylanicum) bark oil on testicular antioxidant values, apoptotic germ cell and sperm quality. Andrologia 2013;45:248-55. [CrossRef]
46. Aghaei S, Nikzad H, Taghizadeh M, Tameh AA, Taherian A, Moravveji A. Protective effect of Pumpkin seed extract on sperm characteristics, biochemical parameters and epididymal histology in adult male rats treated with Cyclophosphamide. Andrologia 2014;46:927-35. [CrossRef]

47. Kolahdooz M, Nasri S, Modarres SZ, Kianbakht S, Huseini HF. Effects of Nigella sativa L. seed oil on abnormal semen quality in infertile men: A randomized, double-blind, placebo-controlled clinical trial. Phytomedicine 2014;21:901-5. [CrossRef]

48. Khani B, Bidgoli SR, Moattar F, Hassani H. Effect of sesame on sperm quality of infertile men. J Res Med Sci 2013;18:184-7. https:/www.ncbi.nlm.nih.gov/pmc/articles/PMC3732896/

49. Mansour SW, Sangi S, Harsha S, Khaleel MA, Ibrahim ARN. Sensibility of male rats fertility against olive oil, Nigella sativa oil and pomegranate extract. Asian Pac J Trop Biomed 2013;3:56368. [CrossRef]

50. Salgado RM, Marques-Silva MH, Gonçalves E, Mathias AC, Aguiar JG, Wolff P. Effect of oral administration of Tribulus terrestris extract on semen quality and body fat index of infertile men. Andrologia 2017;49:e12655. [CrossRef]

51. Hosseini J, Mardi Mamaghani A, Hosseinifar H, Sadighi Gilani MA, Dadkhah F, Sepidarkish M. The influence of ginger (Zingiber officinale) on human sperm quality and DNA fragmentation: A double-blind randomized clinical trial. Int J Reprod Biomed (Yazd, Iran) 2016;14:533-40. [CrossRef]

52. Banihani SA. Effect of ginger (Zingiber officinale) on semen quality. Andrologia 2019;51:e13228. [CrossRef] https://doi. org/10.1111/and.13228

53. Baazeem A, Boman JM, Libman J, Jarvi K, Zini A. Microsurgical varicocelectomy for infertile men with oligospermia: Differential effect of bilateral and unilateral varicocele on pregnancy outcomes. BJU Int 2009;104:524-8. [CrossRef]

54. Agarwal A, Hamada A, Esteves SC. Insight into oxidative stress in varicocele-associated male infertility: Part 1. Nat Rev Urol 2012;9:678-90. [CrossRef]

55. Kizılay F, Altay B. Evaluation of the effects of antioxidant treatment on sperm parameters and pregnancy rates in infertile patients after varicocelectomy: a randomized controlled trial. Int J Impot Res 2019;31:424-31. [CrossRef]

56. Chen YW, Niu YH, Wang DQ, Li H, Pokhrel G, Xu H, et al. Effect of adjuvant drug therapy after varicocelectomy on fertility outcome in males with varicocele-associated infertility: Systematic review and meta-analysis. Andrologia 2018;50:e13070. [CrossRef]

57. Borrelli F, Colalto C, Delfino D V., Iriti M, Izzo AA. Herbal Dietary Supplements for Erectile Dysfunction: A Systematic Review and Meta-Analysis. Drugs 2018;78:643-73. [CrossRef]

58. Xu Y, Xin H, Wu Y, Guan R, Lei H, Fu X, et al. Effect of icariin in combination with daily sildenafil on penile atrophy and erectile dysfunction in a rat model of bilateral cavernous nerves injury. Andrology 2017;5:598-605. [CrossRef]

59. Wu YN, Liao CH, Chen KC, Liu SP, Chiang HS. Effect of Ginkgo biloba Extract (EGb-761) on Recovery of Erectile Dysfunction in Bilateral Cavernous Nerve Injury Rat Model. Urology 2015;85:1214.e7-15. [CrossRef]

60. Santos CA, Reis LO, Destro-Saade R, Luiza-Reis A, Fregonesi A. Tribulus terrestris versus placebo in the treatment of erectile dysfunction: A prospective, randomized, double-blind study. Actas Urológicas Españolas (English Ed) 2014;38:244-8. [CrossRef]

61. Kamenov Z, Fileva S, Kalinov K, Jannini EA. Evaluation of the efficacy and safety of Tribulus terrestris in male sexual dysfunction-A prospective, randomized, double-blind, placebocontrolled clinical trial. Maturitas 2017;99:20-6. [CrossRef]

62. Shin BC, Lee MS, Yang EJ, Lim HS, Ernst E. Maca (L. meyenii) for improving sexual function: A systematic review. BMC Complement Altern Med 2010;6:44. [CrossRef] 